\title{
ACCIDENTS IN MINING AND QUARRY SITES: RATE OF OCCURRENCES AND CAUSES
}

\author{
NURAZLINAABD RAHMAN* \\ MUHAMMAD ARIFPIN MANSOR** \\ AHMAD RASDAN ISMAIL***
}

\begin{abstract}
Abstrak
Kajian ini mengkaji kadar berlakunya kemalangan dan sebab-sebab berlakunya kemalangan di tapak perlombongan dan kuari di Pantai Timur Malaysia. Terdapat dua kaedah yang digunakan dalam kajian ini. Teknik data sekunder telah digunakan dengan mengumpulkan semua laporan kemalangan dari Jabatan Keselamatan dan Kesihatan Pekerjaan (JKKP) di Pantai Timur Malaysia, dan Pertubuhan Keselamatan Sosial (PERKESO), Malaysia. Data digunakan untuk mengenal pasti punca kemalangan, manakala kaedah untuk mengenal pasti kadar kejadian kemalangan adalah melalui soal selidik. Kaedah deskriptif statistik seperti kekerapan, peratusan dan min digunakan dalam analisis. Kajian ini mendedahkan bahawa kemalangan berlaku pada kadar yang lebih rendah di tapak perlombongan dan kuari di Malaysia. Sebabsebab yang berbeza berpuncanya kemalangan telah dikenal pasti seperti objek terbang atau serpihan, laman berantakan, kegagalan kenderaan, mencubit semasa melakukan kerja, tergelincir dan perjalanan pada kawasan kerja, peralatan yang rosak dan jentera, kecuaian pekerja atau kesilapan pengendali, bekerja di tepi tajam, dan jatuh dari ketinggian. Objektif utama kajian ini mencadangkan bahawa langkahlangkah kawalan yang berkenaan perlu dibuat untuk mengurangkan kadar kemalangan.
\end{abstract}

Kata-kata Kunci: Keselamatan, Perlombongan dan Kuari, Punca, Kemalangan 


\begin{abstract}
This study examines the rate of occurrence of accidents and their causes in mining and quarry sites in East Coast Malaysia. There are two methods that were used in this study. The secondary data technique was used by gathering all accident reports from Department of Occupational Safety and Health (DOSH) in East Coast Malaysia, and Social Security Organization (SOCSO), Malaysia. The data was used to identify the causes, while the method to identify the rate of accident occurrences is questionnaires. Descriptive tools of statistics such as frequency, percentage and mean were used for the analysis. The study reveals that accidents occur at a low rate at the mining and quarry sites in Malaysia. Different causes of accident were identified such as flying objects or debris, untidy sites, failure of vehicles, pinched while performing work, slip and trip at work areas, faulty equipment and machinery, negligence of workers or operator's errors, work at sharp edges, and fall from height. This study therefore recommends that relevant control measures should be devised in order to reduce the rate of accident.
\end{abstract}

Keywords: Safety, Mining and Quarry, Causes, Accidents

Post Graduate Student at Faculty of Engineering Technology, University Malaysia Pahang

** Senior Lecturer at Faculty of Engineering Technology, University Malaysia Pahang

*** Assoc. Prof. at Faculty of Creative Technology and Heritage, Universiti Malaysia Kelantan, Malaysia 
Accident can be described as an unpleasant and unexpected event that causes injuries, damages to property and could result in death. Mwombeki (2005) views accident as an unplanned and unexpected occurrence, which upsets a planned sequence of work resulting in loss of production, injuries of personnel, damages of plant and equipment, and eventually in interruption of production flow. Nowadays, workplace accident occurs every day and it becomes worse and known to be a major concern in almost all types of industry. Most sectors such as manufacture, construction and agriculture industry, there are high recorded numbers of accident reported. Hence, there are a lot of previous studies highlighting the characteristics (Said, 2011), causes (Abdel Hamid, 2000) and the rates of accident in those sectors (Abdullah, 2011). However, there have been lack of study for other sectors such as mining and quarry sectors. Thus, this research intends to examine the frequency of occurrence and causes for different types of accidents at mining and quarry sites in East Coast Malaysia.

\subsection{Literature Review}

Mining and quarrying sites seem to be similar to construction sites but mines and quarries are less risky when compared to constructions which are known for high rate of occupational accidents, which shows that those locations are the most dangerous workplaces on earth (I.L.O., 2005). There is a number of accidents recorded in this mining and quarrying industry, but the number becomes less when compared to other industries such as manufacture and construction industries. This can be shown in Table 1, with occupational accident statistics in different sectors. It is clearly shown that mining and quarrying sectors recorded smaller number of victims.

\begin{tabular}{|c|c|c|c|}
\hline \multirow[b]{2}{*}{ Occupational Sectors } & \multicolumn{3}{|c|}{ Number of victims } \\
\hline & Death (D) & $\begin{array}{l}\text { Non Permanent } \\
\text { Disability (NPD) }\end{array}$ & $\begin{array}{l}\text { Permanent } \\
\text { Disability (PD) }\end{array}$ \\
\hline Manufacturing & 47 & 1007 & 93 \\
\hline Mining and Quarrying & 1 & 17 & 0 \\
\hline Construction & 36 & 55 & 9 \\
\hline $\begin{array}{l}\text { Agricultural, For estry, } \\
\text { Logging and Fishing }\end{array}$ & 26 & 286 & 9 \\
\hline Util ity & 0 & 65 & 0 \\
\hline $\begin{array}{l}\text { Transport, storage and } \\
\text { Communication }\end{array}$ & 7 & 54 & 1 \\
\hline Wholesale and Ret ail Trade & 3 & 54 & 5 \\
\hline Hotel and Restaurant & 0 & 7 & 1 \\
\hline $\begin{array}{l}\text { Financial, insurance, Real } \\
\text { Estate and Business Services }\end{array}$ & 0 & 48 & 1 \\
\hline $\begin{array}{l}\text { Public Services and } \\
\text { Statutory Bodies }\end{array}$ & 0 & 50 & 0 \\
\hline
\end{tabular}


However, the data also shows an increment of the rate of accidents at mining and quarrying sites from day to day. Seixas et al (1998) mention that the occurrence of accident differs from one site to another. They further ascertained that strip and trip, major fall from heights, electrical accidents, impact hazards and so on are the major causes of the accidents or most frequent type of accidents happen at work sites. This means that one site could be more dangerous than the other, depending on the complexity of the work carried out at the site. However, different factors responsible for the occurrence of accidents can be grouped as:

i. $\quad$ Acts Of God:

Siriwardena et al (2006) said that the acts of God or disasters related to accidents at sites are events or actions, which cause severe damages to property, processes and stakeholders. Various acts of God or so call natural disasters that cause casualties on sites are rain, flood, wind, lightning, earthquakes, land sliding, and etc. However, their occurrences are not frequent, but once they occur, the consequences are always high and disrupt activities of construction enterprises. Siriwardena et al (2006) further state that the effect of the acts of God or disasters to constructed items or items under construction has a huge direct impact on human lives, society and the economy. In other words, they could result in loss of lives, money, property and time. Therefore, from the inception to the delivery of a mining and quarrying work project, safety procedures must be complied at sites.

ii. Environmental Causes:

Environmental factors that could generate accidents on sites are:

- Weather

Adeniye (2001) states that during the rainy seasons, many materials are wasted and manpower is lost on sites. Thus, because of this environmental condition, it is much easier to carry out works on site during the dry season than the wet season. Sotire (1992) also points out that workers work on an unsheltered environment, adverse weather conditions should be avoided because continuous exposure to adverse weather could lead to general discomfort and illness. 
- Noise

Continuous exposure to moderately high noise level or relatively high level of impulse noise such as explosives on site, noise produced by heavy equipment, noise from carpentry works, crushing works and mechanical works on site are the major causes of occupational deafness (Adeniye, 2001). Thus, continual exposure to this high level of noise produced on site could risk a site worker to future or occupational deafness or hearing problem; if effective control such as earplug is not provided and used. Therefore, noise on sites must be maintained at a bearable level or a noise protection provided.

- Dust

Dust is a common feature of any mining and quarrying site especially during dry seasons (Sotire, 1992). Exposure of workers to dust on site continuously could lead to eye problem, cough and respiratory disorder and allergies. Crushing works process are the major producers of dust on site. Their inhalation could result in bodily and medical disorder on the workers; therefore, proper protection against dust on site must be provided for all site workers.

iii. Faulty Machines (vehicles):

Though human errors are the main causes of accidents on sites, many mechanical causes of accidents are due to internal mechanical breakdown involving the steering mechanism, brake system, etc (Fischer, 1998). According to Fischer (1998), a loader collided with the wall of a building as a result of the machine suddenly became unsteerable. The reason was a broken rear axle bearing of the machine while in operation; which is a mechanical fault. Though the loader was in perfect condition before the time of accident, it developed mechanical fault that resulted to accident. Conditions of machine such as brakes, steering, oil level, water level and tyre conditions must be checked before being operated to prevent any forms of mechanical fault that could develop thereafter.

iv. Human Error:

Human error was considered to be an undesirable human decision or action that reduces or has the potential for reducing the effectiveness, safety or system performance (Lucy et al, 1999). They further ascertained that almost all of accidents, whether minor or major, resulted

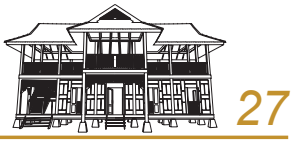


from the action of individuals rather than externally imposed factors. This error could be due to failures on the part of workers themselves while on site, as a result of unsafe attitude of the workers, error in judgments, lack of concentration at work, lack of awareness on the danger surrounding the activities and safety requirements. Thus, there must be adequate safety training for all workers and personnel on site to raise their awareness level about safety, ensuring safe attitude on site and in return, reducing the potential of occurrence of accident on sites.

\subsection{Materials and Methods}

There are two types of methods that were used in this research. For the causes of accidents, the data was gathered from the secondary data from accident reports that were administered from Department of Occupational Safety and Health, Social Security Organization (SOCSO) and from record registered from chosen mining and quarrying companies in East Cost Malaysia as East Coast Malaysia were chosen as the population in this study. The data collected includes personal information of victims, types and causes of accident, time and date of accident, gender, position, process involved during accident and body injured data. About 60 data of accidents were gathered to find the causes of accident in mining and quarrying industry in East Coast Malaysia.

The second method is by using simple questionnaires to meet the other objective in order to identify the occurrences of accident. The questionnaire contains the name of mining or quarrying company and their names, the respondents' profession, position, academic and professional qualifications, and years of experience. It also sought the opinions of the respondents on the frequency of occurrence of six types of accidents identified from literatures and their causes. These subjective opinions were measured on Likerttype scales using 1 to represent never, 2 for low, 3 for average and 4 for high. 30 returned questionnaires were administered from the respondents who were mostly general workers at mining and quarrying site such as driller, truck driver and etc, site engineers and safety officers (where available). The data collected were then analyzed using descriptive analytical tools such as frequency, percentage and mean. 


\subsection{Results and Discussion}

4.1 Cause of Accident at mining and quarrying site

The different causes of accidents at mining and quarrying sites are shown in Table 2. It can be inferred from the Table that six types of accidents and 17 causes exist at mining and quarrying sites in Malaysia. It also reveals that flying objects (slip/trip/fall/cut accident) is the most common causes of accident on sites, this is followed by slip and trip at work area which also falls underslip/ trip/fall/cut accident and pinched while performed work (conveyer accidents). It can be observed from Table 2 the least cause of accidents on site is fire and explosive accidents. This is probably because most mining and quarrying site do not produce too much ignition that can cause fire.

\begin{tabular}{lllll}
\hline Types of Accidents & Identified Causes & N & $\begin{array}{c}\text { Percentage } \\
\text { (\%) }\end{array}$ & Frequency \\
Slip/Trip/Fall/Cut A ccidents & Fall from height & 60 & 6.67 & 4 \\
& Slip and trip at work area & 60 & 11.67 & 7 \\
& Work at sharp edge & 60 & 10.00 & 6 \\
& Flying objects & 60 & 13.33 & 8 \\
Vehicle A ccidents & Unsecured Load & 60 & 333 & 2 \\
& Contact with vehicle & 60 & 333 & 2 \\
& Operator's Error & 60 & 833 & 5 \\
& Failureof vehicle & 60 & 6.67 & 4 \\
Conveyer Accidents & Flying object from conveyer & 60 & 1.67 & 1 \\
& Negligence of workers & 60 & 1.67 & 1 \\
Chemical/water splash Accidents & Pinched while perform work & 60 & 11.67 & 7 \\
Faulty Machinery A ccidents & Inrush of water & 60 & 6.67 & 4 \\
& Unsuitable PPE & 60 & 333 & 2 \\
& Electrical Shodk & 60 & 333 & 2 \\
Fire and Explosive A ccident & Faulty Tools and equipment & 60 & 5.00 & 3 \\
& Improper fixing of components & 60 & 1.67 & 1 \\
& Availability of ignition sources & 60 & 1.67 & 1
\end{tabular}

Note: $\mathrm{N}$ represents the Total number of accident record register ed 
4.2 Rate of Occurrence of Accidents on Sites.

Table 3: Rate of Occurrence of Accidents on sites.

\begin{tabular}{lcc}
\hline Occurrence of Accidents & Frequency & Percentage (\%) \\
\hline High & 1 & 3.3 \\
Average & 6 & 20.0 \\
Low & 22 & 73.3 \\
Never & 2 & 6.7 \\
\hline Total & 30 & 100.0 \\
\hline
\end{tabular}

Table 3 shows the rate of occurrence of accidents at mining and quarrying sites as indicated by the respondents. One can inferred from the Table that the rate of occurrence of accidents at mining and quarrying sites is low but varies from site to site. This is because 22 out of 33 respondents signify that it is low; while six, two and one of them indicates that it is average, never and high respectively. This result agrees with Seixas et al (1998) finding that the occurrence of accident on sites differs from one site to another depending on the complexity of the work area at mining and quarrying site.

\subsection{Conclusions and Recommendation}

The study reveals that:

i. Six types of accidents from 17 causes exist at mining and quarrying site at East Coast Malaysia.

ii. The commonest accidents are slip, trip, fall, and cut accidents with flying object while the least is fire and explosions

iii. The rate of occurrence of accidents is low. 
The survey therefore recommends that:

i. Practitioners should be cognizant of these accidents and their causes identified in this study in projects' execution.

ii. The death's rate of these accidents should be studied empirically and established quantitatively in Malaysia

iii. Control measures should be investigated and relevant ones evolved for all mining and quarrying site in Malaysia

\subsection{Acknowledgement}

The authors would like to express gratitude to Department of Occupational Safety and Health, Malaysia (DOSH) and Social Security Organization (SOCSO) for sharing some info and to Universiti Malaysia Pahang (UMP) for providing funding to this research.

\section{References}

Abdelhamid, T.S. and Everett, J.G. 2000. Identifying of root causes of construction accident. Journal of Construction Engineering and Management, ASCE; 52-60.

Abdullah D. N. M. A. and Wern G. C.M., 2011. An Analysis of Accident Statistics in Malaysian Construction Sector. International Conference on E-business, Management and Economics IPEDR

Adeniye, A.A. 2001. Health and safety on construction sites. Journal of Nigerian Institute of Building.

Department of Occupational Safety and Health. Occupational accidents statistics by sector until August 2013, Retrieved November 22, 2013. http://www.dosh.gov.my/index.php?option=com_content\&view=arti cle\&id=843\&ltemid=545\&lang=en.

Fischer, H.W. 1998. Contractors' Plants and equipments Insurance in International Market (Revised Edition). Zurich: Swiss Reinsurance Company.

Guo Wei-ci \& Wu Chao, 2011. Comparative Study on Coal Mine Safety between China and the US from

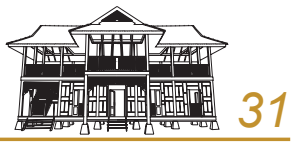


a Safety Sociology Perspective.

I.L.O. 2005. Prevention: A Global Strategy. Promoting safety and Health at Work. The ILO Report for World Day for Safety And Health at Work, International Labour Office, Geneva, 2005. ISBN 92-2-117107-8.

L. Song, X.Q. He. and C. W. Li. 2011. Longitudinal relationship between economic development and occupational accidents in China. Accident Analysis and Prevention 43: 82-86.

Lucy, J.S., lan, J., \& lan, V. 1999. Increasing Construction Productivity Through Total Loss Control: Journal of R.I.C.S Research Foundation, COBRA. Pg 266-276.

McCann, M., and Paine, D. 2002. When is a fall not a fall? In Power Through Partnerships: 12th Annual Construction Safety and Health Conference, Proceedings (May 21-23, 2002, Rosemont, IL).

O.S.H.A. 2002. Construction Industry Digest: Occupational Safety and Health Administration (Revised Edition). U.S Department of Labour.

Said S. M., Halim Z. A., \& Said F. 2011. Workplace Injuries in Malaysian Manufacturing Industries. Scientific Conferece on Occupational Safety and Health (SCl-COSH).

Seixas et al., 1998. Exposure Assessment for Acute Injuries on Comstruction Sites: Conceptual Development and Pilot Test.

Siriwardena N.U., Haigh, R.P., and Ingirige, M.J.B. 2006. Disaster! In Search of Definition: Specific construction Industry. Journal of Research Institute for the Built Environment, University of Salford.U.K. Pg 249-257.

Sotire, O.O 1992. A Comparative Study of Safety Measures in Indigenous and Multinational construction Firms in Nigeria. M.Sc Thesis, Department of Building, University of Lagos, Nigeria.

U.S Department of Labour. 2005. Accidents in construction industry of Hong Kong (2000-2004). Accidents Analysis and Information Division. Labour Department.

Zakaria. N.H., Mansor. N, Abdullah. Z. 2012. Workplace Accident in Malaysia: Most Common Causes and Solutions. Business and Management Review: 2(5): 75-88. 